\title{
Bacteriological and Molecular Characterization of Salmonella Species Isolated from Humans and Chickens in Sharkia Governorate, Egypt
}

\author{
Heba A. Ahmed*, Rasha M. Gharieb, Mohamed E.M. Mohamed, Magda A. Amin and Rehab E. \\ Mohamed \\ Zoonoses Department, Faculty of Veterinary Medicine, Zagazig University, 44511, Egypt
}

\begin{abstract}
This study was carried out to investigate the occurrence of Salmonella species in 690 different samples collected from Sharkia Governorate, Egypt. The samples comprised of chicken meat, organs, eggs, cloacal swabs and wooden surface swabs from pluck shop outlets and hand swabs from workers. In addition, stool swabs from patients with gastroenteritis attending the Outpatient Clinics at Zagazig and Abo-Hammad cities. Salmonella spp. were detected in 5.9\%, 2.6\%, 4.2\%, $10.4 \%, 10 \%$ and $10 \%$ of chicken meat, organs, egg shell, cloacal swabs, surface swabs and hand swabs, respectively. The isolation rate from stool swabs was $0.8 \%$. Biochemical Identification revealed that Salmonella spp. were identified in 129 out of 690 examined samples (18.7\%). Meanwhile, molecular identification using invA gene revealed that only 29 Salmonella isolates were detected (4.2\%). S. Typhimurium and $S$. Enteritidis were identified from different samples with the percentages of 1.2 and 1.01, respectively. The other identified Salmonella serovars were $S$. Newport $(0.9 \%), S$. Kentucky $(0.7 \%)$, and $S$. Infantis $(0.4 \%)$. Virulence associated genes including avrA, hilA and pef were identified in 100, 91.3 and $10.3 \%$ of the examined isolates. In conclusion, a proportion of chicken carcasses and giblets sold in Sharkia Governorate, Egypt was contaminated with Salmonella spp. including potentially virulent $S$. Typhimurium and $S$. Enteritidis, posing risk for human consumers.
\end{abstract}

Keywords: Salmonella, Serotyping, PCR, avrA, hilA, pef

\section{Introduction}

Salmonella is an important foodborne pathogen with an estimated 1.3 billion incidences of nontyphoidal salmonellosis worldwide annually [1]. More than 2500 Salmonella serotypes are recognized, of which, $S$. Enteritidis, $S$. Typhimurium and $S$. Kentucky are identified as the most frequently causative agents causing disease burden on consumers [2]. Poultry is incriminated in many outbreaks of human salmonellosis worldwide, which in turn causes concern to public health [3]. Traditional identification methods including phenotyping and serotyping are time consuming and labor intensive. For these reasons, the use of PCR for identification of Salmonella serovars is an attractive alternative to the most traditional techniques. Salmonellaspecific PCR with primers for the invasion (invA) gene is a rapid, sensitive, and specific tool for monitoring Salmonellae at the genus level in a variety of clinical samples [4]. The invA gene encodes a protein in the inner membrane of bacteria, which is necessary for invasion of epithelial cells of the host [5]. Several reports had also confirmed the successful detection of $100 \%$ of Salmonella isolates from poultry using specific primers for the invA gene with no false positives or negative [6-8]. Salmonella spp. had some genes responsible for its virulence, for instance, the $a v r \mathrm{~A}$; is an effector protein of the type three secretion system (TTSS) complex that contributes to the virulence of Salmonella spp. by limiting the host's inflammatory response through the inducement of cell apoptosis, especially macrophages $[9,10]$. Also, the hyper invasive locus A (hilA) gene is one of the important virulence determinants which is necessary for the expression of the TTSS components required to invade epithelial cells $[11,12]$. The plasmid encoded fimbriae (pefA) gene plays an important role in the pathogenicity of Salmonella spp. because the fimbriae promote their attachment to epithelial cells [13]. This study was planned to estimate the occurrence of Salmonella serovars in chickens and humans inhabiting the same areas using bacteriological and molecular methods. Salmonella isolates were further characterized by virulence gene profiling, focusing on three virulence determinants associated with SPIs and plasmids that have been shown to be relevant

*Corresponding author email: (heba_ahmed@zu.edu.eg), Zoonoses Department, Faculty of Veterinary 48 Medicine, Zagazig University, 44511, Egypt. 
for the success of Salmonella as an intracellular pathogen.

\section{Material and Methods}

\section{Sampling}

A total of 690 different samples from AboHammad and Zagazig cities, Sharkia Governorate were collected for the isolation of Salmonella species. The samples comprised of 152 chicken meat samples (breast and thigh,76, each), 152 chicken organs (liver and heart, 76, each), 140 egg samples (egg shell and contents, 70, each), 76 cloacal swabs and 20 surface swabs from wooden cutting boards at poultry pluck shop outlets. In addition, 20 hand swabs from poultry workers at the outlets and 130 human stool samples from Outpatient Clinic at Hospitals in Abo-Hammad and Zagazig, Sharkia Governorate, Egypt were collected. The study was conducted during the period from November 2016 to April 2017. The collected samples were immediately transported to the laboratory for bacteriological analysis.

\section{Isolation and bacteriological identification}

Twenty-five grams from raw chicken meat (breast and thigh) and organs (liver and heart) samples were homogenized in $225 \mathrm{~mL}$ of buffered peptone water (BPW, Oxoid) and incubated at $37^{\circ} \mathrm{C}$ for $24 \mathrm{~h}$ for pre-enrichment. Sterile swabs were used to sample the egg shells and then, they were incubated in BPW tubes. After sterilization of the egg shells, it was cracked and the contents were mixed with BPW. All other swab samples (cloacal, hand, stool and surface swabs) were collected in BPW tubes and pre-enriched as previously described.

Isolation of Salmonella spp. was carried out according to ISO-6579: 2002 standard [14, 15]. Following pre-enrichment in BPW, a portion $(0.1 \mathrm{~mL})$ of the pre-enriched broth was transferred to $10 \mathrm{~mL}$ Rappaport-Vassiliadis Soy Peptone (RVS, Oxoid) broth followed by incubation at $41.5^{\circ} \mathrm{C}$ overnight $(18-24 \mathrm{~h})$. Another portion (one $\mathrm{mL}$ ) from pre-enriched broth was added to $10 \mathrm{~mL}$ of MullerKauffmann Tetrathionate/Novobiocin broth (Oxoid), and then incubated at $37^{\circ} \mathrm{C}$ for $24 \mathrm{~h}$. From each enrichment broth, a loopful was streaked onto the surface of Xylose Lysine Desoxycholate (XLD, Oxoid) agar and Hekton
Enteric agar (Oxoid) and the plates were incubated at $37^{\circ} \mathrm{C}$ for $24 \mathrm{~h}$. The suspected colonies were purified and then identified morphologically and biochemically using Gram staining and biochemical screening tests including oxidase test reactions on triple sugar iron agar, indole production, carbon utilization in Simmon's citrate agar and urea hydrolysis [16].

\section{Molecular identification of Salmonella spp.}

Identification of genus Salmonella was performed using the invasion gene (invA) specific primer pairs F-139 5'-GTG AAA TTA TCG CCA CGT TCG GGC AA-3 and R-141 5-TCA TCG CAC CGT CAA AGG AAC C3' which produce $284 \mathrm{bp}$ amplicon size [8]. The reaction was performed in a volume of 25 $\mu \mathrm{L}$ containing $12.5 \mu \mathrm{L}$ of readymade power Emerald Amp GT PCR Mastermix (Takara), 20 pmol of each primer and $6 \mu \mathrm{L}$ of the purified DNA. A negative control (no added DNA) and a positive control ( $S$. Enteritidis) was also run. The positive control was kindly provided by the Reference Laboratory for Veterinary Quality Control on Poultry Production, Animal Health Research Institutes, Giza.

The reaction conditions consisted of a primary denaturation at $94^{\circ} \mathrm{C}$ for $5 \mathrm{~min}$, followed by 35 cycles of denaturation at $94^{\circ} \mathrm{C}$ for $30 \mathrm{sec}$, annealing at $55^{\circ} \mathrm{C}$ for $30 \mathrm{sec}$ and extension at $72^{\circ} \mathrm{C}$ for $30 \mathrm{sec}$, followed by a final extension at $72^{\circ} \mathrm{C}$ for $7 \mathrm{~min}$. The PCR products $(10 \mu \mathrm{L})$ were mixed with loading buffer $(3 \mu \mathrm{L})$ and loaded in $1.5 \%$ agarose gel beside $5 \mu \mathrm{L}$ of 100 bp DNA ladder (Qiagen, USA). The gels were then run in $1 x$ TBE and 5 uM ethidium bromide (Sigma) for at least 45 min at 100 volts and then visualized using ultraviolet transilluminator (Gel Documentation System, Consort-Belgium).

\section{Serotyping}

Molecularly confirmed Salmonella isolates were subjected to serotyping following the Kauffmann-White Scheme with commercial antisera (Difco Laboratories Detroit) for cell wall (O) and flagellar $(\mathrm{H})$ antigen identification [Kauffmann and DasKauffmann, 2001)]. Serotyping was carried out at the Bacteriology Department, Faculty of Veterinary Medicine, Benha University. 
Molecular identification of S. Enteritidis and S. Typhimurium

Molecular confirmation of S.Enteritidis and $S$. Typhimurium, was further carried out using primer sets specific for $S$. Typhimurium with the sequences F: 5'GGT GGC AAG GGA ATG AA-3 and R: 5'CGC AGC GTA AAG CAA CT-3 [17] and $S$. Enteritidis with the sequences F: 5-GCA GCG GTT ACT ATT GCA GC-3 and R: 5'-TGT GAC AGG GAC ATT TAG CG-3' [18] producing amplicons with molecular weight of $915 \mathrm{bp}$ and $310 \mathrm{bp}$, respectively. The amplification mixture composition and visualization of the products were as previously described for invA PCR. The reaction conditions for $S$. Typhimurium STM4495 consisted of a primary denaturation at $94^{\circ} \mathrm{C}$ for $5 \mathrm{~min}$, followed by 35 cycles of denaturation at $94^{\circ} \mathrm{C}$ for $30 \mathrm{sec}$, annealing at $50^{\circ} \mathrm{C}$ for $1 \mathrm{~min}$ and extension at $72^{\circ} \mathrm{C}$ for 1 min followed by final extension at $72^{\circ} \mathrm{C}$ for 10 min. While, the reaction conditions for $S$. Enteritidis sefA PCR consisted of a primary denaturation at $94^{\circ} \mathrm{C}$ for $5 \mathrm{~min}$, followed by 35 cycles of denaturation at $94^{\circ} \mathrm{C}$ for $30 \mathrm{sec}$, annealing at $52^{\circ} \mathrm{C}$ for $30 \mathrm{sec}$, extension at $72^{\circ} \mathrm{C}$ for $30 \mathrm{sec}$ and then a final extension at $72^{\circ} \mathrm{C}$ for $7 \mathrm{~min}$.

\section{Molecular identification of virulence associated genes}

Molecular detection of three virulence associated genes: hilA F: 5'-CAT GGC TGG TCA GTT GGA G-3' and R: 5'-CGT AAT TCA TCG CCT AAA CG-3' [19], pefA F: 5'TGT TTC CGG GCT TGT GCT-3'and R: 5'CAG GGC ATT TGC TGA TTC TTC C3'[20], and $a v r A$ F: 5'-CCT GTA TTG TTG AGC GTC TGG-3' and R: 5'-AGA AGA GCT
TCG TTG AAT GTC C-3' [21] producing amplicons with molecular sizes of $150 \mathrm{bp}$, $700 \mathrm{bp}$ and $422 \mathrm{bp}$, respectively. The reaction mixture composition and visualization were as previously described for invA PCR. The reaction conditions for the three genes consisted of a primary denaturation at $94^{\circ} \mathrm{C}$ for 5 min, followed by 35 cycles of denaturation at $94^{\circ} \mathrm{C}$ for $30 \mathrm{sec}$, annealing at $60^{\circ} \mathrm{C}$ for 30 $\sec \left(\right.$ hil A), $58^{\circ} \mathrm{C}$ for $45 \sec (a v r \mathrm{~A}), 55^{\circ} \mathrm{C}$ for $45 \mathrm{sec}$ (pefA), extension at $72^{\circ} \mathrm{C}$ for $45 \mathrm{sec}$ and a final extension at $72^{\circ} \mathrm{C}$ for $10 \mathrm{~min}$.

\section{Results and Discussion}

\section{Identification of Salmonella spp.}

Bacteriological examination revealed that $18.7 \%$ of the samples under investigation were suspected to be contaminated with Salmonella species (Table 1). However, molecular amplification of the invA gene revealed that only $4.2 \%$ were confirmed. In accordance, de Freitas et al. [22] have reported that increased uncertainty in morphological and biochemical testing is attributed to variations among Salmonella strains. The rapidity and higher accuracy of PCR compared to bacteriological typing methods is promising in diagnosis of infections $[17,23]$.

The invA gene is used as a marker for the molecular identification of the genus [17, 23] and was widely used for the detection of Salmonella spp. in different samples. Consistent with our findings, invA gene was amplified in $100 \%$ of Salmonella serovars isolated from chicken and humans in Egypt [6, 24-26].

Table 1: Proportion of salmonella isolates identified by bacteriological and molecular testing in different samples

\begin{tabular}{lcc}
\hline Samples & $\begin{array}{c}\text { No. of bacteriologically suspected } \\
\text { isolates }(\boldsymbol{\%})\end{array}$ & $\begin{array}{c}\text { No. of molecularly confirmed } \\
\text { Salmonellae* }\end{array}$ \\
\hline Chicken Meat $(\mathbf{n = 1 5 2})$ & $30(19.7 \%)$ & $9(5.9 \%)$ \\
Chicken Organs $(\mathbf{n = 1 5 2})$ & $26(17.1 \%)$ & $4(2.6 \%)$ \\
Chicken Egg $(\mathbf{n = 1 4 0})$ & $17(12.1 \%)$ & $3(2.1 \%)$ \\
Cloacal swabs $(\mathbf{n = 7 6})$ & $23(30.3 \%)$ & $8(10.5 \%)$ \\
Surface swabs $(\mathbf{n}=\mathbf{2 0})$ & $6(30 \%)$ & $2(10 \%)$ \\
Hand swabs(n=20) & $3(15 \%)$ & $2(10 \%)$ \\
Stool swabs(n=130) & $24(18.5 \%)$ & $1(0.8 \%)$ \\
Total (n=690) & $129(18.7 \%)$ & $29(4.2 \%)$ \\
\hline
\end{tabular}

*Molecular identification was based on amplification of $i n v \mathrm{~A}$ gene. 
The most prevalent zoonotic Salmonella serovars in the current study (Table 2) upon serotyping were $S$. Typhimurium $(1.2 \%)$ and $S$. Enteritidis (1.01\%), followed by $S$. Newport $(0.9 \%), S$. Kentucky $(0.7 \%)$ and $S$. Infantis $(0.4 \%)$

Human non-typhoidal salmonellosis is mainly caused by $S$. Typhimurium and $S$. Enteritidis [17, 27]. Different primers specific for molecular identification of $S$. Typhimurium and $S$. Enteritidis were developed to target $\mathrm{O}$ antigens, $\mathrm{H} 1$ and $\mathrm{H} 2$ antigens [28-30]. At least five primer sets should be used to amplify these antigens, rendering these primers in appropriate for routine diagnosis [17]. Primers targeting stm-4495 gene of $S$. Typhimurium are more sensitive and specific for the identification of $S$. Typhimurium [17]. A sequence in $S$. Enteritidis SEF14 fimbrial antigen gene (sefA) were used for developing primer sets specific for the diagnosis of the serovar [31]. In the current study, stm-4495 and sefA genes were respectively detected in all $S$. Typhimurium $(\mathrm{n}=8)$ and all $S$.Enteritidis $(n=7)$ isolates using corresponding specific primers that produced amplicons with molecular weight of $915 \mathrm{bp}$ and $310 \mathrm{bp}$, respectively (Figures 1,2). The sefA gene was reported in $100 \%$ of $S$. Enteritidis isolates from human gastroenteritis cases [31], meat products in Egypt [32] and poultry [33].

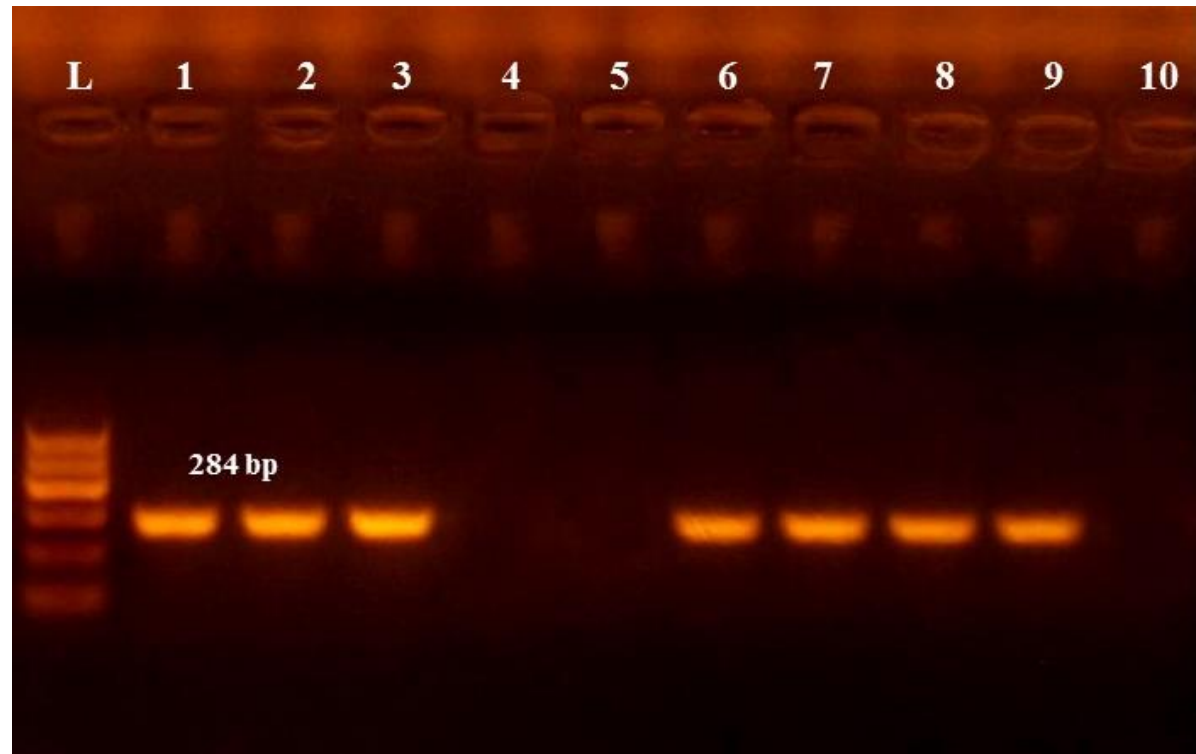

Figure 1: Sample of gel picture showing amplification of $284 \mathrm{bp}$ of $\operatorname{invA}$ gene for the molecular identification of Salmonella species from different sources. L: 100 bp ladder, lanes 1-8: examined samples, 9: Positive control of Salmonella DNA obtained from the Biotechnology Unit, Reference laboratory for Veterinary Quality Control on Poultry Production, Animal Health Research Institute, Dokki, Giza, Egypt, 10: Negative control.

\section{Occurrence of Salmonella spp. in different samples}

The overall isolation rate of Salmonella spp. from chicken meat samples in the current study (Table 2) was $5.9 \%$. Such percentage was nearly similar to $6,9.8$ and $5 \%$ previously reported in India [34], China [35] and Egypt [26], respectively. Slightly higher percentages of 10.6 and 11.8 were reported in Croatia [36] and India [37], respectively. However, higher isolation rates of $14 \%$ [38] and 44\% [39] from chicken meat were reported in Egypt. The difference in prevalence rates between different studies could be attributed to diversity in sampling methods, season and isolation techniques [40].

The results in Table (2) showed the isolation of Salmonella spp. from breast $(6.6 \%)$ and thigh muscles (5.2\%). Higher percentages of Salmonella spp. isolation from breast meat; $15.4 \%$ in Croatia [36], $26 \%$ in Egypt [41] and 20\% in Egypt [42] were previously reported. While, higher prevalence rates of isolation from thigh muscles; $33.3 \%$ [42] and 33\% [43] were also documented. 


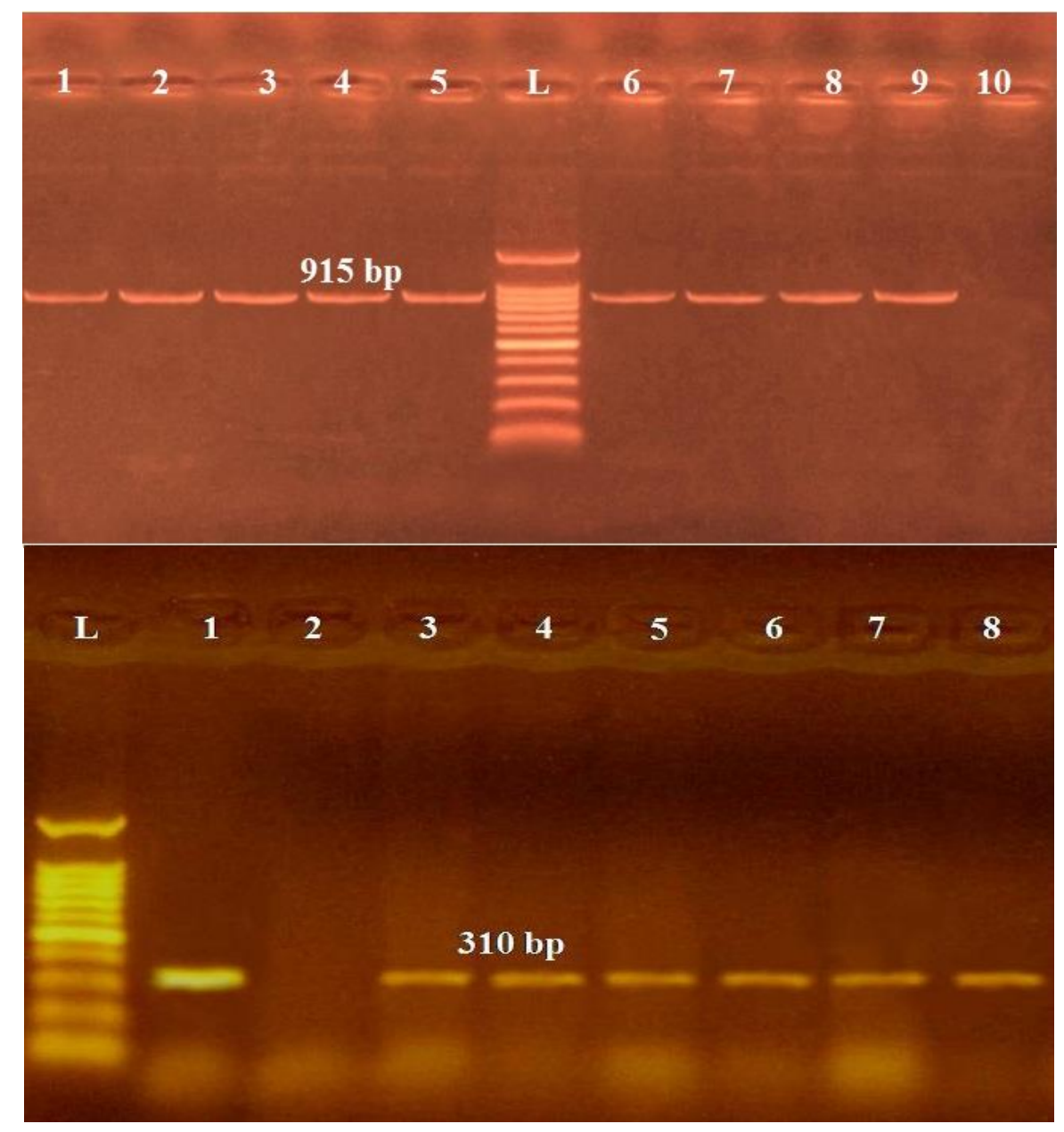

Figure 2: (Upper): Sample of gel picture showing amplification of 915bp for the molecular identification of $S$. Typhimurium from different sources. L: 100 bp ladder, lanes 1-8: examined samples, 9: Positive control of $S$. Typhimurium DNA, 10: Negative control. (Lower): Sample of gel picture showing amplification of 310bp for the molecular identification of $S$. Enteritidis from different sources. L: 100 bp ladder, Lane 1: Positive control of $S$. EnteritidisDNA,2: Negative control, lanes 3-8: examined samples. Positive controls were obtained from the Biotechnology Unit, Reference laboratory for Veterinary Quality Control on Poultry Production, Animal Health Research Institute, Dokki, Giza, Egypt.

Contamination of poultry meat is usually originated from microorganisms present in the intestinal tract, on skin and feather during feather plucking, evisceration, washing and storage [36]. Although the low contamination rate of chicken meat in the study area, hygienic sanitation methods during poultry rearing, transportation, slaughtering, evisceration, in addition to, cross contamination from cutting boards, knives, equipment and hands of workers, should be applied to minimize public health risk [44].

Salmonella spp. were isolated from $2.6 \%$ of liver and heart samples, each (Table 2). Nearly similar percentage of $5.6 \%$ for Salmonella spp. in liver samples were previously recorded in Egypt [45]. The percentage of Salmonella spp. isolated from heart samples during the current study was nearly similar to $6 \%$ in Iran [46]. In contrary, higher percentages of $48 \%$ and $14.1 \%$ were reported in Egypt [39] and Iran [40], respectively. The previously reported high isolation of Salmonellae from liver and heart samples could be attributed to the contamination of these organs from the crop and the intestinal contents during evisceration [47]. 
Table 2: Occurrence of Salmonella species in the examined samples

\begin{tabular}{|c|c|c|c|c|c|c|c|}
\hline Samples & Number examined & S. Typhimurium & $S$. Enteritidis $S$ & Sentucky S & S. Newport & S. Infantis & Total \\
\hline Meat & 152 & $\begin{array}{c}1 \\
(0.7 \%)\end{array}$ & $\begin{array}{c}2 \\
(1.3 \%)\end{array}$ & $\begin{array}{c}2 \\
(1.3 \%)\end{array}$ & $\begin{array}{c}2 \\
(1.3 \%)\end{array}$ & $\begin{array}{c}2 \\
(1.3 \%)\end{array}$ & $\begin{array}{c}9 \\
(5.9 \%)\end{array}$ \\
\hline Breast & 76 & 0 & $\begin{array}{c}2 \\
(2.6 \%)\end{array}$ & $\begin{array}{c}1 \\
(1.3 \%)\end{array}$ & $\begin{array}{c}1 \\
(1.3 \%)\end{array}$ & $\begin{array}{c}1 \\
(1.3 \%)\end{array}$ & $\begin{array}{c}5 \\
(6.6 \%)\end{array}$ \\
\hline Thigh & 76 & $\begin{array}{c}1 \\
(1.3 \%)\end{array}$ & 0 & $\begin{array}{c}1 \\
(1.3 \%)\end{array}$ & $\begin{array}{c}1 \\
(1.3 \%)\end{array}$ & $\begin{array}{c}1 \\
(1.3 \%)\end{array}$ & $\begin{array}{c}4 \\
(5.2 \%)\end{array}$ \\
\hline Organs & 152 & $\mathbf{0}$ & $\begin{array}{c}3 \\
(2 \%)\end{array}$ & $\mathbf{0}$ & $\begin{array}{c}1 \\
(0.7 \%)\end{array}$ & $\mathbf{0}$ & $\begin{array}{c}4 \\
(2.6 \%)\end{array}$ \\
\hline Liver & 76 & 0 & $\begin{array}{c}2 \\
(2.6 \%)\end{array}$ & 0 & 0 & 0 & $\begin{array}{c}2 \\
(2.6 \%)\end{array}$ \\
\hline Heart & 76 & 0 & $\begin{array}{c}1 \\
(1.3 \%)\end{array}$ & 0 & $\begin{array}{c}1 \\
(1.3 \%)\end{array}$ & 0 & $\begin{array}{c}2 \\
(2.6 \%)\end{array}$ \\
\hline Egg shell & 70 & $\begin{array}{c}1 \\
(1.4 \%)\end{array}$ & 0 & $\begin{array}{c}1 \\
(1.4 \%)\end{array}$ & $\begin{array}{c}1 \\
(1.4 \%)\end{array}$ & 0 & $\begin{array}{c}3 \\
(4.2 \%)\end{array}$ \\
\hline Egg content & 70 & 0 & 0 & 0 & 0 & 0 & 0 \\
\hline Cloacal swabs & 76 & $\begin{array}{c}2 \\
(2.6 \%)\end{array}$ & $\begin{array}{c}1 \\
(1.3 \%)\end{array}$ & $\begin{array}{c}2 \\
(2.6 \%)\end{array}$ & $\begin{array}{c}2 \\
(2.6 \%)\end{array}$ & $\begin{array}{c}1 \\
(1.3 \%)\end{array}$ & $\begin{array}{c}8 \\
(10.4 \%)\end{array}$ \\
\hline Surface swabs & 20 & $\begin{array}{c}1 \\
(5 \%)\end{array}$ & $\begin{array}{c}1 \\
(5 \%)\end{array}$ & 0 & 0 & 0 & $\begin{array}{c}2 \\
(10 \%)\end{array}$ \\
\hline Hand swabs & 20 & $\begin{array}{c}2 \\
(10 \%)\end{array}$ & 0 & 0 & 0 & 0 & $\begin{array}{c}2 \\
(10 \%)\end{array}$ \\
\hline Stool swabs & 130 & $\begin{array}{c}1 \\
(0.8 \%)\end{array}$ & 0 & 0 & 0 & 0 & $\begin{array}{c}1 \\
(0.8 \%)\end{array}$ \\
\hline Total & 690 & $\begin{array}{c}8 \\
(1.2 \%) \\
\end{array}$ & $\begin{array}{c}7 \\
(1.01 \%) \\
\end{array}$ & $\begin{array}{c}5 \\
(0.7 \%)\end{array}$ & $\begin{array}{c}6 \\
(0.9 \%) \\
\end{array}$ & $\begin{array}{c}3 \\
(0.4 \%)\end{array}$ & $\begin{array}{c}29 \\
(4.2 \%)\end{array}$ \\
\hline
\end{tabular}

Salmonella enterica could be transmitted to humans following consumption of contaminated eggs produced by infected laying hens. There was an association between the contamination of eggs and egg products with Salmonella and human infection [48]. The results shown in Table (2) verified that $4.2 \%$ of egg shell samples were contaminated with Salmonella species. Comparable isolation rates from egg shell samples were previously recorded in Egypt [49, 50]. However, higher isolation rates of $20 \%$ in India [34] and 34\% in Spain [51] were documented.

Absence of Salmonellae in the contents of eggs (Table 2), was consistent to other findings [51]. In contrary, in India, Nagappa et al. [52], and different studies in Egypt [49, 50, 53] detected Salmonella spp. in egg content samples. The low and sporadic egg content contamination could be attributed to the protective effect of complex system membrane barriers and the antibacterial effect of egg albumin [51].

The results in Table (2) showed that $10.4 \%$ of the examined cloacal swabs were positive for Salmonella species. Similarly, in Egypt, Abd El-Ghany et al. [45] isolated Salmonella spp. from $6.3 \%$ of cloacal swabs. Moreover, higher isolation rates of $64.5 \%$ in Bangladesh [54] and 92\% in India [55] were documented. Lower rates of $2.6 \%$ in Northern Thailand [56] and 4\% in Spain [51] were reported.

Meat contact surfaces are considered sources of contamination of meat served for human consumption [57]. In the present study, $10 \%$ of the surface swabs from wooden cutting boards were contaminated with Salmonella spp. (Table 2). A study in Nigeria reported the isolation of Salmonella spp. in meat contact surfaces [57]. Contamination of the cutting borads could be originated from water used in washing. Another study in Nigeria revealed that no Salmonellae were isolated from the wooden surface swabs in poultry outlets [58]. The variation in the isolation rates from the wooden contact surfaces indicates variation in hygienic practices applied during processing in the pluck shop outlets. Other studies reported the identification of Salmonella spp. in chopping boards at retail chicken outlets with the percentage of 18.8 in India [59] and $100 \%$ in Malaysia [60].

Salmonella infection in humans frequently occurs as a result of cross contamination from 
equipment, utensils and workers' hands due to subsequent handling of raw carcasses and products. In addition, consumption of under cooked poultry meat is another important route of transmission [47]. Table (2) shows that the overall prevalence of Salmonella spp. in 130 examined stool samples of human participants residing the same localities from which chicken samples were obtained was $0.8 \%$. Nearly similar results of 1.3 and $2 \%$ were reported in Japan [61] and Egypt [50], respectively. In Egypt, 10\% [62], 6\% [41] and $4 \%$ [38] prevalence rates of Salmonellae in stool samples were reported.

The frequency of Salmonella spp. in hand swabs from workers at pluck shop outlets was $10 \%$ (Table 2). Nearly similar results of $14.3 \%$ in India [59] and 8.9\% in Egypt [63] were reported. However, Ahmed et al. [41] documented that $4 \%$ of hand swabs collected from poultry pluck shop workers in Dakahlia, Egypt, were contaminated with Salmonellae. Therefore, hand cleaning and disinfection before and after contact with eggs and chicken carcasses are essential to minimize the risk of cross contamination [64].

\section{Serotypes identified in the examined samples}

$S$. Typhimurium and $S$. Enteritidis are the most predominant isolated organisms in most cases associated with the consumption of contaminated poultry and their products [65]. The predominance of $S$. Typhimurium $(1.2 \%)$ followed by $S$. Enteritidis $(1.01 \%)$ and $S$. Newport $(0.9 \%)$ in the current study was in concordance with the Centers for Disease Control and Prevention (CDC) [66]. In addition, the predominant serovars present in Egyptian poultry farms are $S$. Typhimurium and $S$. Enteritidis[25, 45]. In contrary, a study in Egypt, reported that $S$. Enteritidis predominated and was followed by $S$.
Typhimurium in samples of chicken origin [47].

The identification of $S$. Typhimurium in different samples during the current study highlights the importance of such serovar to pose a potential risk to poultry consumers and pluck shop workers. $S$. Enteritidis has shown an increase in frequency in different parts of the world in the last two decades [67]. It is also the most predominant serovar associated with chicken egg production [61].

$S$. Kentucky currently ranks among top ten serovars causing gastroenteritis in humans [68]. The poultry source of this serovar was previously reported [69]. Isolation rates of $41 \%, 20 \%, 14.3 \%$ and $10.8 \%$ for $S$. Kentucky isolated from chicken samples were reported in Ireland [70], USA [71] and Egypt [43, 47], respectively.

The isolation of $S$. Newport from chickens was previously reported in Patna [37], Northeastern Thailand [13] and Iran [40] with the percentages of $2.6 \%, 1.3 \%$ and $8 \%$, respectively. The $\mathrm{CDC}$ annual summary identified $S$. Enteritidis, $S$. Typhimurium and $S$. Kentucky as the most frequent causative agents causing disease burden on consumers in the United States [2].

In the present study, $S$. Infantis was only identified in chicken meat samples and cloacal swabs $(1.3 \%$, each). Likewise, Kaushik et al. [37] isolated $S$. Infantis from poultry meat in India with an isolation rate of $0.4 \%$. Also, isolation of this serovar from broiler flocks suggested that chicken meat is one of the sources for human infection [61, 72, 73]. $S$. Infantis has been reported previously in Japan from asymptomatic cases and food handlers [61]. 


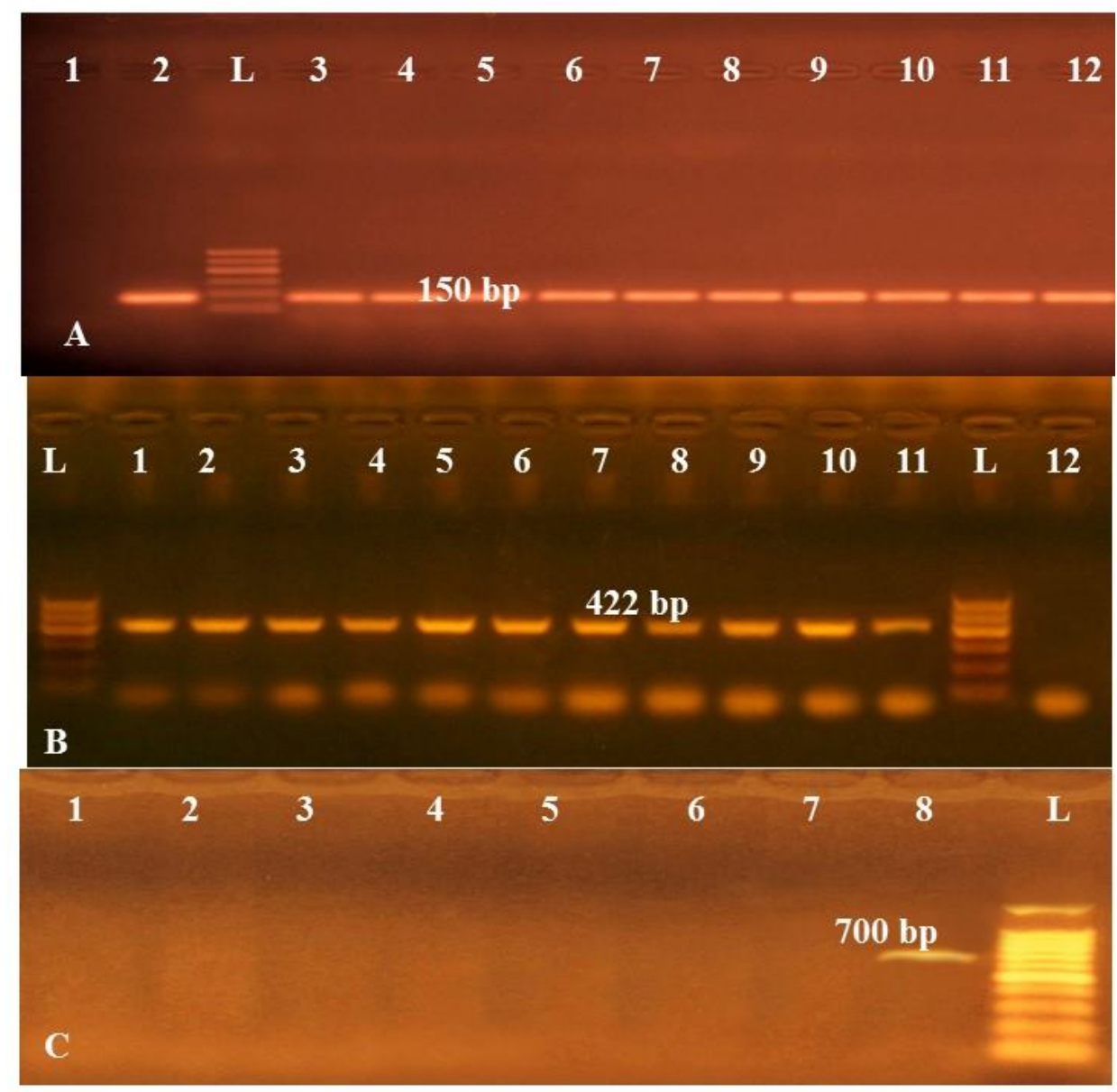

Figure 3: Sample of gel picture showing amplification of different virulence associated genes in Salmonella serovars. A: 150 bp of hilA gene, B: 422 bp of avrA gene, C: 700 bp of pefA gene. L: 100 bp ladder.

\section{Molecular identification of virulence associated genes}

Various virulence determinants in Salmonella spp. are associated with chromosomal and plasmid factors [8]. All 29 identified Salmonella strains were subjected to PCR genotyping for detection of some virulence determinants. The results revealed the detection of avrA, hilA and pef genes in $100,91.3$ and $10.3 \%$ of the examined isolates (Figure 3). The detection of avrA gene in $100 \%$ of Salmonella isolates was also reported in other studies $[12,24]$. However, lower frequencies of $80 \%$ [74] and 50\% [75] were reported in Salmonella enterica isolates. This variation could be attributed to recombination which frequently occurs in the location of this gene [76]. Consistent with the current results of hilA gene, it was previously identified in 100 and $88.2 \%$ of Salmonellae isolated from chicken samples in Brazil [12] and Egypt [6], respectively. While the gene was identified in
8.3\% [38] and $8.6 \%$ [18] of Salmonella isolates. Regarding to results of pef gene, the obtained low frequency of pefA gene was comparable with other findings [24, 77]. However different studies in Egypt reported the detection of the gene with higher frequencies ranging from $100 \%$ [38] to $41.2 \%$ [6]. The considerable differences in virulence determinants of Salmonella serovars are attributed to the variation in sample sources, types of serovars and presence or absence of plasmids carrying virulence associated genes [78].

\section{Conclusion}

It could be concluded that a proportion of chicken carcasses and giblets sold in Sharkia, Egypt is contaminated with Salmonella spp., predominantly $S$. Typhimurium and $S$. Enteritidis. the majority of the isolates harbored virulence associated genes, hence, chicken meat and their products constitute a significant problem for public health. Thus, 
this calls for better measures to control cross contamination of poultry meat during slaughter and handling with pathogenic bacteria must be taken.

\section{Conflict of interest}

The authors declare no conflict of interest.

\section{References}

[1] Coburn, B.; Grassl, G.A. and Finlay, B.B. (2007): Salmonella, the host and disease: a brief review. Immunol Cell Biol, 85(2): 112-118.

[2] Bugarel, M.; Tudor, A.; Loneragan, G.H. and Nightingale, K.K. (2017): Molecular detection assay of five Salmonella serotypes of public interest: Typhimurium, Enteritidis, Newport, Heidelberg, and Hadar. J Microbiol Methods, 134: 14-20.

[3] Dallal, M.M.S.; Doyle, M.P.; Rezadehbashi, M.; Dabiri, H.; Sanaei, M.; Modarresi, S.; Bakhtiari, R.; Sharifiy, K.; Taremi, M.; Zali, M.R. and Sharifi-Yazdi, M.K. (2010): Prevalence and antimicrobial resistance profiles of Salmonella serotypes, Campylobacter and Yersinia spp. isolated from retail chicken and beef, Tehran, Iran. Food Control, 21(4): 388-392.

[4] Osman, K.M.; Yousef, A.M.; Aly, M.M. and Radwan, M.I. (2010): Salmonella spp. infection in imported 1-day-old chicks, ducklings, and turkey poults: a public health risk. Foodborne Pathog Dis, 7(4): 383-390.

[5] Darwin, K.H. and Miller, V.L. (1999): Molecular Basis of the Interaction of Salmonella with the Intestinal Mucosa. Clin Microbiol Rev, 12(3): 405-428.

[6] Ammar, A.M.; Mohamed, A.A.; Abd ElHamid, M.I. and El-Azzouny, M.M. (2016): Virulence genotypes of clinical SalmonellaSerovars from broilers in Egypt. J Infect Dev Ctries, 10(4): 337-346.

[7] Moussa, I.M.; Gassem, M.A.; Al-Doss, A.A.; Sadik, W.A.M. and Mawgood, A.A. (2010): Using molecular techniques for rapid detection of Salmonella serovars in frozen chicken and chicken products collected from Riyadh, Saudi Arabia. Afr J Biotechnol, 9(5): 612-619.
[8] Oliveira, S.D.; Santos, L.R.; Schuch, D.M.T.; Silva, A.B.; Salle, C.T.P. and Canal, C.W. (2002): Detection and identification of Salmonellas from poultryrelated samples by PCR. Vet Microbiol, 87(1): 25-35.

[9] Ben-Barak, Z.; Streckel, W.; Yaron, S.; Cohen, S.; Prager, R. and Tschape, H. (2006): The expression of the virulenceassociated effector protein gene avrA is dependent on a Salmonella entericaspecific regulatory function. Int $\mathrm{J}$ Med Microbiol, 296(1): 25-38.

[10] Collier-Hyams, L.S.; Zeng, H.; Sun, J.; Tomlinson, A.D.; Bao, Z.Q.; Chen, H.; Madara, J.L.; Orth, K. and Neish, A.S. (2002): Cutting edge: Salmonella AvrA effector inhibits the key proinflammatory, anti-apoptotic NFkappa B pathway. J Immunol, 169(6): 2846-2850.

[11] Bajaj, V.; Lucas, R.L.; Hwang, C. and Lee, C.A. (1996): Co-ordinate regulation of Salmonella typhimurium invasion genes by environmental and regulatory factors is mediated by control of hilA expression. Mol Microbiol, 22(4): 703714.

[12] Borges, K.A.; Furian, T.Q.; Borsoi, A.; Moraes, H.L.S.; Salle, C.T.P. and Nascimento, V.P. (2013): Detection of virulence-associated genes in Salmonella Enteritidis isolates from chicken in South of Brazil. Pesq Vet Bras, 33(12): 14161422.

[13] Sinwat, N.; Angkittitrakul, S. and Chuanchuen, R. (2015): Characterization of Antimicrobial Resistance in Salmonella enterica Isolated from Pork, Chicken Meat, and Humans in Northeastern Thailand. Foodborne Pathog Dis, 12(9): 759-765.

[14] ISO-6579. (2002): Microbiology of food and animal feeding stuffs for detection of Salmonella. https://www.iso.org/standard/29315.html

[15] ISO-6579. (2007): Detection of Salmonella species in animal feces and in environmental samples from the 
primary production stage. https://www.iso.org/standard/42109.html

[16] Murray, P.R.; Baron, E.J.O.; Pfaller, M.A.; Jorgensen, J.H. and Yolken, R.H. Manual of clinical microbiology 8th Ed. ed. Washington D.C: Asm Press; 2003.

[17] Liu, B.; Zhou, X.; Zhang, L.; Liu, W.; Dan, X.; Shi, C. and Shi, X. (2012): Development of a novel multiplex PCR assay for the identification of Salmonella enterica Typhimurium and Enteritidis. Food Control, 27(1): 87-93.

[18] Akbarmehr, J. (2010): Isolation of Salmonella spp. from poultry (ostrich, pigeon, and chicken) and detection of their hilA gene by PCR method. Afr J Microbiol Res, 4(24): 2678-2681.

[19] Mizusaki, H.; Takaya, A.; Yamamoto, T. and Aizawa, S. (2008): Signal pathway in salt-activated expression of the Salmonella pathogenicity island 1 type III secretion system in Salmonella enterica serovar Typhimurium. J Bacteriol, 190(13): 4624-4631.

[20] Rahman, H.; Prager, R. and Tschape, H. (2000): Occurrence of sef \& pef genes among different serovars of Salmonella. Indian J Med Res, 111: 40-42.

[21] Huehn, S.; La Ragione, R.M.; Anjum, M.; Saunders, M.; Woodward, M.J.; Bunge, C.; Helmuth, R.; Hauser, E.; Guerra, B.; Beutlich, J.; Brisabois, A.; Peters, T.; Svensson, L.; Madajczak, G.; Litrup, E.; Imre, A.; Herrera-Leon, S.; Mevius, D.; Newell, D.G. and Malorny, B. (2010): Virulotyping and antimicrobial resistance typing of Salmonella enterica serovars relevant to human health in Europe. Foodborne Pathog Dis, 7(5): 523-535.

[22] de Freitas, C.G.; Santana, A.P.; da Silva, P.H.; Goncalves, V.S.; Barros Mde, A.; Torres, F.A.; Murata, L.S. and Perecmanis, S. (2010): PCR multiplex for detection of Salmonella Enteritidis, Typhi and Typhimurium and occurrence in poultry meat. Int $\mathrm{J}$ Food Microbiol, 139(1-2): 15-22.

[23] Kardos, G.; Farkas, T.; Antal, M.; Nogrady, N. and Kiss, I. (2007): Novel
PCR assay for identification of Salmonella enterica serovar Infantis. Lett Appl Microbiol, 45(4): 421-425.

[24] Ahmed, H.A.; El-Hofy, F.I.; Shafik, S.M.; Abdelrahman, M.A. and Elsaid, G.A. (2016): Characterization of Virulence-Associated Genes, Antimicrobial Resistance Genes, and Class 1 Integrons in Salmonella enterica serovar Typhimurium Isolates from Chicken Meat and Humans in Egypt. Foodborne Pathog Dis, 13(6): 281-288.

[25] El-Sharkawy, H.; Tahoun, A.; ElGohary, A.E.-G.A.; El-Abasy, M.; ElKhayat, F.; Gillespie, T.; Kitade, Y.; Hafez, H.M.; Neubauer, H. and ElAdawy, H. (2017): Epidemiological, molecular characterization and antibiotic resistance of Salmonella enterica serovars isolated from chicken farms in Egypt. Gut Pathog, 9: 8.

[26] Tarabees, R.; Elsayed, M.S.A.; Shawish, R.; Basiouni, S. and Shehata, A.A. (2017): Isolation and characterization of Salmonella Enteritidis and Salmonella Typhimurium from chicken meat in Egypt. J Infect Dev Ctries, 11(4): 314319.

[27] Xia, S.; Hendriksen, R.S.; Xie, Z.; Huang, L.; Zhang, J.; Guo, W.; Xu, B.; Ran, L. and Aarestrup, F.M. (2009): Molecular Characterization and Antimicrobial Susceptibility of Salmonella Isolates from Infections in Humans in Henan Province, China. J Clin Microbiol, 47(2): 401-409.

[28] Echeita, M.A.; Herrera, S.; Garaizar, J. and Usera, M.A. (2002): Multiplex PCR-based detection and identification of the most common Salmonella secondphase flagellar antigens. Res Microbiol, 153(2): 107-113.

[29] Muñoz, N.; Diaz-Osorio, M.; Moreno, J.; Sánchez-Jiménez, M. and CardonaCastro, N. (2010): Development and Evaluation of a Multiplex Real-Time Polymerase Chain Reaction Procedure to Clinically Type Prevalent Salmonella enterica Serovars. J Mol Diagn, 12(2): 220-225. 
[30] Tennant, S.M.; Diallo, S.; Levy, H.; Livio, S.; Sow, S.O.; Tapia, M.; Fields, P.I.; Mikoleit, M.; Tamboura, B.; Kotloff, K.L.; Nataro, J.P.; Galen, J.E. and Levine, M.M. (2010): Identification by PCR of non-typhoidal Salmonella enterica serovars associated with invasive infections among febrile patients in Mali. PLoS Negl Trop Dis, 4(3): e621.

[31] Pan, T.M. and Liu, Y.J. (2002): Identification of Salmonella enteritidis isolates by polymerase chain reaction and multiplex polymerase chain reaction. J Microbiol Immunol Infect, 35(3): 147151.

[32] Abd El-Tawab, A.A.; El-Hofy, F.I.; Alekhnawy, K.I. and Sharaf, D.M. (2015): Detection of Salmonella Enteritidis in some meat products by using PCR. Benha Vet Med J Bacteriol, 28(2): 202-207.

[33] Akbarmehr, J. (2011): A survey on the prevalence of poultry salmonellosis and detection of different Salmonella serovars isolated from poultry in broiler chicken farms. Afr J Microbiol Res, 5(32): 5950-5954.

[34] Anumolu, V.K. and Lakkineni, V.R. (2012): Screening of poultry samples for Salmonella Typhimurium by PCR assay. Vet World, 5(3): 169-172.

[35] Li, R.; Lai, J.; Wang, Y.; Liu, S.; Li, Y.; Liu, K.; Shen, J. and Wu, C. (2013): Prevalence and characterization of Salmonella species isolated from pigs, ducks and chickens in Sichuan Province, China. Int J Food Microbiol, 163(1): 1418.

[36] Kozačinski, L.; Hadžiosmanović, M. and Zdolec, N. (2006): Microbiological quality of poultry meat on the Croatian market. Veterinarski Arhiv, 76(4): 305313.

[37] Kaushik, P.; Anjay Kumari, S.; Bharti, S.K. and Dayal, S. (2014): Isolation and prevalence of Salmonella from chicken meat and cattle milk collected from local markets of Patna, India. Vet World, 7(2): 62-65.
[38] Gharieb, R.M.; Tartor, Y.H. and Khedr, M.H. (2015): Non-Typhoidal Salmonella in poultry meat and diarrhoeic patients: prevalence, antibiogram, virulotyping, molecular detection and sequencing of class I integrons in multidrug resistant strains. Gut Pathog, 7: 34.

[39] Abd El-Aziz, D.M. (2013): Detection of Salmonella typhimurium in retail chicken meat and chicken giblets. Asian Pac J Trop Dis, 3(9): 678-681.

[40] Sodagari, H.R.; Mashak, Z. and Ghadimianazar, A. (2015): Prevalence and antimicrobial resistance of Salmonella serotypes isolated from retail chicken meat and giblets in Iran. J Infect Dev Ctries, 9(5): 463-469.

[41] Ahmed, H.A.; Ibrahim, A.F.; Hussein, M.A. and El Bayomi, R.M. (2014): ERIC-PCR fingerprinting of some $S$. Typhimurium isolates from chicken and humans with reference to the microbiological quality of retail chicken meat in dakahlia, egypt. Glob Vet, 13(1): 95-104.

[42] Khalafalla, F.A.; Abdel-Atty, N.S.; Abdel-Wanis, S.A. and Hanafy, A.S. (2015): Food poisoning microorganisms in chicken broiler meat. Glob Vet, 14(2): 211-218.

[43] Ibrahim, H.M.; Amin, R.A.; Ibrahem, I.A. and Yunis, O.F. (2014): Isolation of Enterobacteriacaeae from poultry products in El-Behera and Alexandria governorates. BVMJ, 27(1): 109-117.

[44] Thakur, Y.R. and Bajaj, B.K. (2006): Antibiotic resistance and molecular characterization of poultry isolates of Salmonella by RAPD-PCR. World J Microbiol Biotechnol, 22(11): 11771183.

[45] Abd El-Ghany, W.; El-Shafii, S. and Hatem, M. (2012): A survey on Salmonella species isolated from chicken flocks in Egypt. Asian J Anim Vet Adv, 7: 489-501.

[46] Rahimi, E. (2012): Prevalence and antimicrobial resistance of Salmonella spp isolated from retail chicken, turkey 
and ostrich by-products in Iran. Revue de Médecine Vétérinaire, 163: 271-275.

[47] Abd-Elghany, S.M.; Sallam, K.I.; AbdElkhalek, A. and Tamura, T. (2015): Occurrence, genetic characterization and antimicrobial resistance of Salmonella isolated from chicken meat and giblets. Epidemiol Infect, 143(5): 997-1003.

[48] Humphrey, T.J. Public Health aspects of Salmonella infection. In: Wray C, Wray A, editors. Salmonella in domestic animals. UK: CABI Publishing; 2000. p. 245-264.

[49] El-Kholy, S.A.I. (2014): The prevalence of Salmonella Enteitidis in ovaries of layer hens at time of slaughtering. MSc thesis, Faculty of Veterinary Medicine: Alexandria University.

[50] Gharieb, R.M. (2008): Studies on some zoonotic bacterial food borne infection. $\mathrm{PhD}$ thesis (Zoonoses), Faculty of Veterinary Medicine: Zagazig University.

[51] Garcia, C.; Soriano, J.M.; Benitez, V. and Catala-Gregori, P. (2011): Assessment of Salmonella spp. in feces, cloacal swabs, and eggs (eggshell and content separately) from a laying hen farm. Poult Sci, 90(7): 1581-1585.

[52] Nagappa, K.; Tamuly, S.; Brajmadhuri; Saxena, M.K. and Singh, S.P. (2007): Isolation of Salmonella Typhimurium from poultry eggs and meat of Tarai region of Uttaranchal. Indian $\mathbf{J}$ Biotechnol, 6: 407-409.

[53] Ismail, N.H.Y. (2014): Potential of some biological hazards associated with table eggs. MSc thesis (Food hygiene and control) Faculty of Veterinary Medicine: Cairo University.

[54] Ahmed, A.K.M.; Islam, M.T.; Haider, M.G. and Hossain, M.M. (2008): Seroprevalence and pathology of naturally infected Salmonellosis in poultry with isolation and identification of causal agents. JBAU, 6(2): 8 .

[55] Ramya, P.; Madhavarao, T. and Rao, L.V. (2012): Study on the incidence of Salmonella enteritidis in poultry and meat samples by cultural and PCR methods. Vet World, 5(9): 541-5.

[56] Hanson, R.; Kaneene, J.B.; Padungtod, P.; Hirokawa, K. and Zeno, C. (2002): Prevalence of Salmonella and E. coli, and their resistance to antimicrobial agents, in farming communities in northern Thailand. Southeast Asian J Trop Med Public Health, 33 Suppl 3: 120-126.

[57] Faleke, O.O.; Jolayemi, K.O.; Igoh, Y.O.; Jibril, A.H. and Ayedun, J.O. (2017): Salmonella species on meat contact surfaces and processing water in sokoto main market and abattoir, nigeria. Macedonian Veterinary Review, 40(1): 59-65.

[58] Ishola, O. and Taiwo, A.D. (2014): Frozen retail poultry meat contact surfaces as sources of Salmonella and Escherichia coli contamination in Ibadan, Oyo State, Nigeria. Am J Infect Dis., 2(4): 81-85.

[59] Suresh, T.; Hatha, A.M.; Srinivasan, D.; Srinivasan, S. and Lakshmanaperumalsamy, P. (2004): Salmonella cross-contamination in retail chicken outlets and the efficacy of spice extracts on Salmonella Enteritidis growth inhibition on various surfaces. Microbes Environ, 19(4): 286-291.

[60] Nidaullah, H.; Abirami, N.; ShamilaSyuhada, A.K.; Chuah, L.O.; Nurul, H.; Tan, T.P.; Abidin, F.W.Z. and Rusul, G. (2017): Prevalence of Salmonella in poultry processing environments in wet markets in Penang and Perlis, Malaysia. Vet World, 10(3): 286-292.

[61] Murakami, K.; Ishihara, T.; Horikawa, K. and Oda, T. (2007): Features of Salmonella serovars among food handlers in Kyushu, Japan. New Microbiol, 30(2): 155-159.

[62] Rabie, N.S.; Khalifa, N.O.; Radwan, M.E.I. and Afify, J.S.A. (2012): Epidemiological and molecular studies of Salmonella isolates from chicken, chicken meat and human in Toukh, Egypt. Glob Vet, 8(2): 128-132. 
[63] Ibrahim, M.A.; Emeash, H.H.; Ghoneim, N.H. and Abdel-Halim, M.A. (2013): Seroepidemiological studies on poultry salmonellosis and its public health importance. J World's Poult Res 3(1): 18-23.

[64] El-Tras, W.F.; Tayel, A.A. and Samir, A. (2010): Potential zoonotic pathways of Salmonella enteritidis in laying farms. Vector Borne Zoonotic Dis, 10(8): 739742.

[65] Capuano, F.; Mancusi, A.; Capparelli, R.; Esposito, S. and Proroga, Y.T. (2013): Characterization of drug resistance and virulotypes of Salmonella strains isolated from food and humans. Foodborne Pathog Dis, 10(11): 963-968.

[66] CDC. (2009): Centers for Disease Control and Prevention. Preliminary Food Net Data on the incidence of infection with pathogens transmitted commonly through food-10 states, 2008 MMWR 58: 333-337 Available: http://www cdcgov/mmwr/preview/mmwrhtml/mm5 813a2htm? Accessed: August 2014.

[67] Rampling, A. (1993): Salmonella enteritidis five years on. Lancet, 342(8867): 317-318.

[68] Bonalli, M.; Stephan, R.; Käppeli, U.; Cernela, N.; Adank, L. and Hächler, H. (2012): Salmonella enterica serotype Kentucky associated with human infections in Switzerland: Genotype and resistance trends 2004-2009. Food Res Int, 45(2): 953-957.

[69] Boyle, F.; Morris, D.; O'Connor, J.; DeLappe, N.; Ward, J. and Cormican, M. (2010): First Report of ExtendedSpectrum- $\beta$-Lactamase-Producing Salmonella enterica Serovar Kentucky Isolated from Poultry in Ireland. Antimicrob Agents Chemother, 54(1): 551-553.

[70] Whyte, P.; Mc Gill, K.; Collins, J.D. and Gormley, E. (2002): The prevalence and PCR detection of Salmonella contamination in raw poultry. Vet Microbiol, 89(1): 53-60.
[71] Parveen, S.; Taabodi, M.; Schwarz, J.G.; Oscar, T.P.; Harter-Dennis, J. and White, D.G. (2007): Prevalence and antimicrobial resistance of Salmonella recovered from processed poultry. J Food Prot, 70(11): 2466-2472.

[72] Nogrady, N.; Toth, A.; Kostyak, A.; Paszti, J. and Nagy, B. (2007): Emergence of multidrug-resistant clones of Salmonella Infantis in broiler chickens and humans in Hungary. J Antimicrob Chemother, 60(3): 645-648.

[73] Wilkins, M.J.; Bidol, S.A.; Boulton, M.L.; Stobierski, M.G.; Massey, J.P. and Robinson-Dunn, B. (2002): Human salmonellosis associated with young poultry from a contaminated hatchery in Michigan and the resulting public health interventions, 1999 and 2000. Epidemiol Infect, 129(1): 19-27.

[74] Streckel, W.; Wolff, A.C.; Prager, R.; Tietze, E. and Tschape, H. (2004): Expression profiles of effector proteins SopB, SopD1, SopE1, and AvrA differ with systemic, enteric, and epidemic strains of Salmonella enterica. Mol Nutr Food Res, 48(7): 496-503.

[75] Zou, W.; Al-Khaldi, S.F.; Branham, W.S.; Han, T.; Fuscoe, J.C.; Han, J.; Foley, S.L.; Xu, J.; Fang, H.; Cerniglia, C.E. and Nayak, R. (2011): Microarray analysis of virulence gene profiles in Salmonella serovars from food/food animal environment. J Infect Dev Ctries, 5(2): 94-105.

[76] Hopkins, K.L. and Threlfall, E.J. (2004): Frequency and polymorphism of sopE in isolates of Salmonella enterica belonging to the ten most prevalent serovars in England and Wales. J Med Microbiol, 53: 539-543.

[77] Chuanchuen, R.; Ajariyakhajorn, K.; Koowatananukul, C.; Wannaprasat, W.; Khemtong, S. and Samngamnim, S. (2010): Antimicrobial resistance and virulence genes in Salmonella enterica isolates from dairy cows. Foodborne Pathog Dis, 7(1): 63-69.

[78] Porwollik, S.; Boyd, E.F.; Choy, C.; Cheng, P.; Florea, L.; Proctor, E. and 
McClelland, M. (2004): Characterization of Salmonella enterica Subspecies I
Genovars by Use of Microarrays. J Bacteriol, 186(17): 5883-5898.

$$
\text { الملخص العربي }
$$

\section{التوصيف البكتريولوجى والجزيئى لأنواع السلمونيلا المستفردة من الآدميين والاجاج بمحافظة الثرقية ـ مصر}

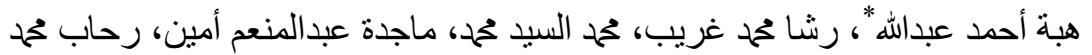$$
\text { قسم الأمر اض المشتركة ـ كلية الطب البيطرى - جامعة الزقازيق } 011 \text { ؛ ؛ مصر }
$$

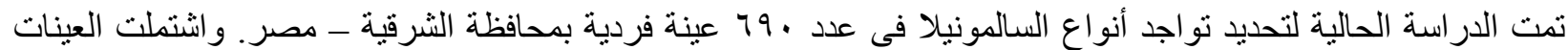

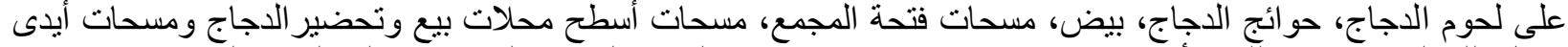

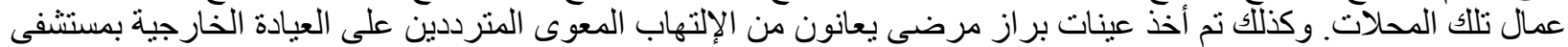

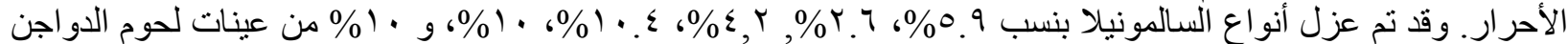

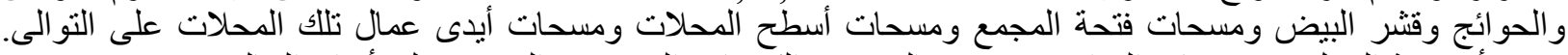

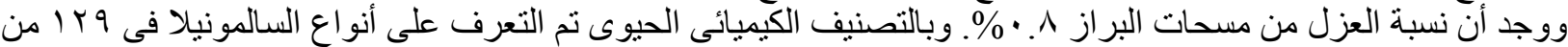

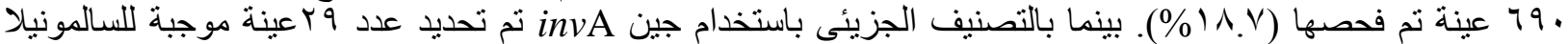

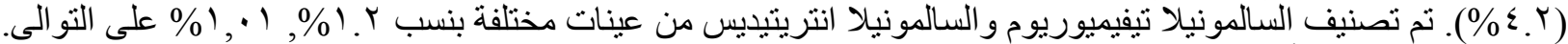

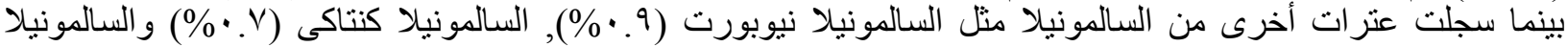

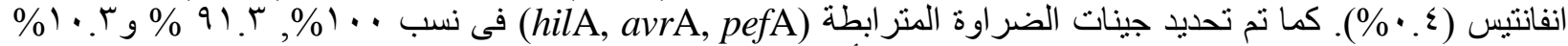

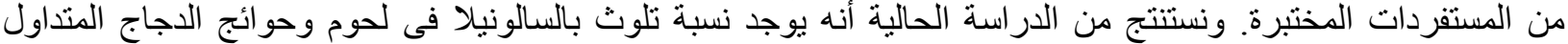

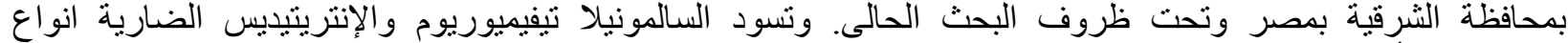
السالمونيلا الأخرى مما يشكل خطر محتمل على المستهالك. 